\title{
Cultural investment of Javanese 'Krama' language in Islamic elementary schools
}

\author{
Khulukul Khuzaefi \\ MI Tegalwaton Semarang \\ khuzaefikhulukul@gmail.com \\ DOI: 10.18326/mudarrisa.v10i2.148-165
}

\begin{abstract}
Language is the most essential communication tool for human beings. Languages possessed by humans are so dynamic that it continues to evolve over time. The language instruction was termed Linguistic Etiquette. In Linguistic Etiquette there is a term of speech levels. The use of language in Islamic Elementary School (Madrasa Ibtidaiyah/MI) was implemented in an integrated manner with the relationshipbetween fields of study. Javanese is the mother tongue of the Javanese. The society levels of speech in Javanese language are Ngoko, Krama Madya, and Krama Inggil. The Javanese practices Krama level language to communicate between students with teachers, among teachers and teachers with headmaster of MI at school. This research was conducted qualitatively to informants from MI Tegalwaton and MI Al Islam Bonomerto. The researcher used qualitative descriptive approach to describe the state or phenomenon status of the data obtained from the research object, which then analyzed. This study are investigating MI programs in instilling Javanese 'Krama' language, the results of Javanese 'Krama' language cultural cultivation in MI Tegalwaton and MI Al Islam Bonomerto as well as obstacles experienced by the students in using Javanese 'Krama' language.
\end{abstract}

Keywords: Javanese 'Krama' language, Islamic elementary school, cultural investment 


\section{INTRODUCTION}

Javanese culture, according to Koentjaraningrat (1981), constitutes the essence of human-being life; one of which is concerning human relationships (Sedyawati, 2003:23). It is taught in Javanese culture about many harmonious social values and politeness in life including speaking Javanese 'Krama' or polite language to others. As stated in sura al-Baqarah verse 83, Allah says:

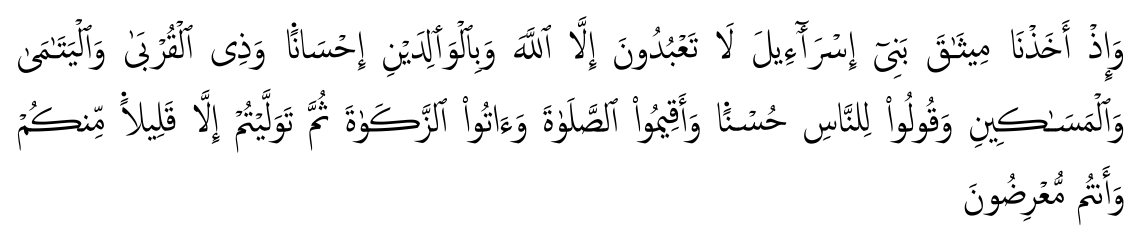

"And (remember), when We took the promise of the Children of Israel: worship none but Allah, and do good to the fathers, the kinsfolk, the orphans, and the poor, and speak the words good to man, establish prayer and pay zakat. Then, you do not fulfill that promise, except a few of you, and you always turn away."

This Javanese speaking culture of Krama level should be taught in various levels of school or madrasa as well as in Javanese family so that the younger generation will maintain and preserve the national identity through its ethnical spoken language. However, this ideal does not fit the reality. After observation coupled with previous research that most schools or madrasa only provide learning theoretical Java language, does not teach the application in the daily life of students. The cause of the decline of interest in Javanese Krama which became the basis of the decline of young people's morality to the value of decency has problems, among others: (1) Parents do not teach the Javanese in everyday communication at home; (2) 


\section{Mudarrisa: Jurnal Kajian Pendidikan Islam, Vol. 10, No. 2, 2018}

Lack of portion of Javanese language lessons at school or madrasa; (3) Superior or extracurricular programs in schools and madrasa are now dominated by foreign cultures such as Arabic, English, Japanese and Mandarin; (4) Refugees change the language for the surrounding environment; (5) lack of ability of teachers in Javanese Krama; (6) Javanese lessons but using introductory Indonesian (7) written applications are used more often than when speaking (Djiwandono, 2014; Utari, 2012).

Students's language skills are not obtained suddenly or simultaneously, but gradually. Their language progress goes hand in hand with their physical, mental, intellectual, and social development. The development of a child's language is characterized by a dynamic balance or a series of unity moving from simple sounds or speech to a more complex speech. Dealing with Javanese cultural values and youth students' behavior, it was indicated a significant relationship between Javanese cultural values and naughty behavior in Javanese adolescents. The higher the attitudes and behaviors that correspond to the Javanese cultural values, the less rogue the behavior that exists in Java adolescents (Rachim \& Anshori, 2007: 34). The process of language development of children is based on these theories. It is concluded that there are three common ways in developing sentences of elementary school children, namely: development, subtraction, and imitation of language (Owens, 2012: 66).

Exploring the Value of Local Wisdom of Javanese Culture through Expressions (Bebasan and Saloka) explains that Javanese phrases contain many moral values that may be accepted by other ethnic groups. They 
include (a) expressions that describe the human relationship with God, (b) expressions that describe human relationships with humans, (c) expressions of attitude and outlook, (d) expressions of strong determination. In addition, there are expressions that reflect bad attitudes and do not need to be developed in everyday life (Sartini, 2009:28-29). The language itself has the meaning of an arbitrary sound symbol system used by members of social groups to cooperate, communicate, and identify (Chaer, 2009: 34). Language Krama's level was an effort designed to influence one's emotional, intellectual, and spiritual to want to learn by his own will which enables student learning.

The Brain Based Learning Approach in Cultural Value Cultivation through Formal Education explains the potential of learners to develop if education provides the widest possible space. This condition will minimize the chance of developing negative attitudes. For that we need to develop a natural learning situation or climate, similar to real and democratic life. Otherwise, children will be deprived of their cultural roots. Brain Based Learning became one of the models to overcome the problem (Anas, 2011: 150). Wedhawati (2006: 57) states that the language rules are termed Linguistic Etiquette.

In Linguistic Etiquette, there is a term of speech levels, ie a code of impolite code of decency based on age level in which there are certain vocabulary elements, certain syntactic rules, certain morphological rules and also certain phonologies. The level of speech in common Javanese is (1) Ngoko, (2) Krama Madya, and (3) Krama Inggil (Poedjosoedarmo, 
2017:7). Each level of speech has its own vocabulary in Javanese. Ngoko's words radiate meaninglessly; The Krama Madya exudes polite meaning (the connotation of respect) but the degree of modesty is somewhat halfhearted; Krama exudes very high connotations of respect, indicating that the speaker was less aware of the truly standard forms of manners.

The children cognitive development was influenced by the environmental conditions, experiences, and information they have, (Suwardi, 2017:220). The learning process was influenced by the learning environment (Budiman, 2017). At this stage, the analyzing process of input or stimulus is in form of speech while production of output or response is in form of material understanding. The Krama level was a process of behavior change as a result between stimulus and response. (Richard, 2009:300; Slavin, 2009:143). It suggested that the role of the environment and school has a great influence on child language cultivation. The aim of processed was achieved by the individual clearly, so this process was done consciously (Ghazali, 2000: 78).

The using of Krama level in MI was conducted in an integrated manner with interrelationships between fields of study. So, the language learning function is as a means of fostering the unity and unity of the nation, increasing knowledge and skills to achieve and develop science, technology and art (Ksuchak, 2009: 256). As the differences, it is discussed in this article the way or steps madrasa manager have taken in the process of cultural cultivation of Javanese Krama, the practice of Javanese in the madrasa as well as the constraints and the ways of resolving them in 


\section{Mudarrisa: Jurnal Kajian Pendidikan Islam, Vol. 10, No. 2, 2018}

Javanese cultural practices of Krama level in MI.

\section{METHODS}

The research used qualitative method to explain a phenomenon using word and sentence (qualitative-descriptive). Qualitative research methods is a process of investigating human related issues in a comprehensive view, composed using sentences, presented in detail from an information and executed in a natural setting (Creswell, 2007: 89). The research was done in MI Tegalwaton, Tengaran region and MI Al Islam Bonomerto, Suruh Regency of Semarang region. Datas were collected and from the subject of research because the practice of good Javanese culture.

The gathering of some information in MI which applies Javanese culture of Krama is in Tengaran Subdistrict and Suruh Subdistrict, Semarang Regency, Central Java. In each place, there is only one MI that applies the Javanese speaking culture of Krama. MI is located in the village Tegalwaton Tengaran District and village Bonomerto Suruh District Semarang District. Practice of Javanese Krama in MI Tegalwaton and MI Al Islam Bonomerto done between students with teacher, teacher with teacher and teacher with head of madrasa. The study was conducted in the madrasa, because of its success in instilling Javanese speaking culture of Krama level with good results so it was interesting to be studied.

Sources of research data, researcher will use data retrieval techniques using in-depth interviews, observation and documentation. Seeking validity of data through triangulation of data is a technique of 
examining the validity of data that utilizes something else by comparing it with various sources, methods, or theories.

\section{RESULTS AND DISCUSSION}

\section{Investment Javanese Culture in MI Tegalwaton}

The findings of field research data show that all MI Tegalwaton supports the cultural investment of Javanese 'Krama' language. It is done through good planning. Investment begins with the establishment of cultural cultivation program of Javanese Krama. The cultivation of Javanese 'Krama' language in MI Tegalwaton first began by analyzing some madrasa programs that support the preservation of local culture and national character. AS said, "I (representing the madrasa) expect each teacher should have prepared how to instill Javanese 'Krama' language before the implementation of teaching and learning process" (AS, 2018: 27 February).

In the program of cultural cultivation of Javanese Krama at MI Tegalwaton, the researcher asked to know about the program, how AS responds to the Javanese culture culture program in MI Tegalwaton. He explained, "About the existence of the Javanese 'Krama' language program, my response good, not only in the general context that is in the community but also in the specific context including the amaliyah aspect that is with the habituation done learners in MI" (AS, 2018: 27 February).

In clarifying about the Javanese 'Krama' language program in MI Tegalwaton, the researcher asked questions about the results obtained from the program. $\mathrm{Tj}$ replied, "The result is a charge that becomes a focal 
point that can be applied and perceived and practiced anywhere" (TJ, 2018: 27 February).

The researcher gave the question to the informant during the interview about how the process of cultural investment of Javanese 'Krama' language in MI Tegalwaton, "Implementation of the process of cultivation of Javanese culture Krama is with the habituation of students such as $4 \mathrm{~S}$ (Smiling, Greetings, accosting, Mannering) in the morning and in the classroom" (NK, 2018: 27 February). Furthermore, Rs added an explanation of the process of cultivating Javanese 'Krama' language, "Implementation is done learner as one example of pembiasannya is in the class of learners using Javanese Krama when asked or answered questions from teachers during the lesson" (RS, 2018: 28 February).

Researcher asked Sl about the steps taken by the MI. Sl replied, "In instilling Javanese 'Krama' language in madrasa that is in the learning activities by all subjects and with other madrasa programs teachers and head madrasa must be accustomed in Javanese manners Krama, so that will facilitate the child in imitating". (Sl, 2018: 28 February)

The researcher gave a question to $\mathrm{Rz}$ as a class teacher, about obstacles in the cultural investment of Javanese 'Krama' language in MI Tegalwaton, "Obstacles, for learners was the lowa bility of Javanese Krama level. Therefore teach it had to be patient and often reminded if there is a mistake". (RZ, 2018: 28 February)

The researcher asked students whether they had difficulty in Javanese manners in madrasa. Hb replied, "there, the difficulty was 
sometimes I was confused to speak Krama level language, but when I was wrong, the teacher often justif". Hb gave information about difficulties firmly (HB, 2018: 28 February). Mi added the answer, "there, the difficulty I spoke the language Krama level, but I mixed with the Indonesian language" (MI, 2018: 27 February).

\section{Investment of Javanese Culture in MI Bonomerto}

The findings of research data in MI Al Islam Bonomerto that the cultivation of Javanese culture of Krama level could be seen from teacher learning device. To understand about the cultivation of Javanese 'Krama' language, hence the researcher give question for informant at the time of interview about how process of cultivation of Javanese 'Krama' language at MI Al Islam Bonomerto, "In the process of cultivation of Javanese 'Krama' language, teachers implement the learning in accordance with RPP. Furthermore, the habitation of Javanese manners that students do every day in the classroom with a classroom teacher or head of the madrasa during the learning takes place. So, we often use two languages in the delivery of material", explained $\mathrm{Mr}$ in answering questions from researcher (MR, 2018: 5 March).

Then $\mathrm{Bn}$ added that the result of the investment of Javanese culture Krama level in MI Al Islam Bonomerto, according to him "The result of the cultivation of Javanese culture Krama that contains the values to be expected is the value of etiquette and courtesy value" (BN, 2018: 5 March). The recognition of $\mathrm{Bn}$ is corroborated by Sw, who also feels the 
importance of Javanese Krama. According to him, "Javanese-speaking culture is implemented through classroom activities and practice in everyday life is very important" (SW, 2018: 5 March).

In clarifying the description of the cultivation of Javanese 'Krama' language, the researcher asked questions to $\mathrm{Rl}$ as a class teacher, about the obstacles in cultural investment of Javanese 'Krama' language in MI Al Islam Bonomerto, "There were obstacles, for students who have not been able to speak Javanese Krama level for teaching patience and patience often, here a teacher should be a good example for learners. Thus, students got a real example of the teachers to teachers (communication) in learning Javanese Krama". Explained Rr when giving information about the obstacles encountered (RL, 2018: 5 March).

The researcher also asks the students whether they are having difficulty in Javanese Krama level at the madrasa. Tw replied, "There are difficulties, because sometimes I am indifferent and confused to ask what at the time of the lesson is difficult", told Tw on giving information about the difficulties (TW, 2018: 6 March). "There is, sometimes forget the proper manners will say with teacher", explained another students, Ss (SS, 2018: 6 March).

Furthermore, the researcher's question relates to the selected solution to overcome the difficulties of cultural cultivation of Javanese Krama level. The solution was that the madrasa provides a disciplinary regulation that must be obeyed by all learners in relation to Javanese speaking Krama level", said Ma giving information about the solution 


\section{Mudarrisa: Jurnal Kajian Pendidikan Islam, Vol. 10, No. 2, 2018}

chosen to overcome difficulties in investment Javanese speaking Krama culture (MA, 2018: 6 March).

Then, Un added that in reality life in MI Al Islam Bonomerto often encountered various violations committed by learners. Un told about the solution used in preventing the violation that usually happened to the learner, according to him "If there were learners who violate the regulation of madrasa discipline then there had to be educational sanction so that the learners will deter and will not repeat the violation" (UN, 2018: 6 March). Furthermore, Mr said, "Usually madrassas provided a punishment to students in the form of memorizing vocabulary Javanese Krama level should be used by learners when violating the madrasa policy" (MR, 2018: 6 March).

Language had the meaning of an arbitrary sound symbol system used by members of social groups to cooperate, communicate, and identify. Language investment was an effort designed to influence one's emotion, intellectual and spiritual to learn on one's own will to enable student learning.

The madrasa program that instills Javanese culture of Krama level was prepared jointly by the head of madrasa, curriculum field, student field, classroom teacher. Based on the results of research known that madrasa program which is a form of cultivation of Javanese culture Krama with habituation program, namely: (1) MI Tegalwaton with Smiling, Greetings, Accosting, Mannering (4S), become a daily habituation in the madrasa environment starting from the morning when students enter the 
gates of the madrasa. Before the class is cultivated to say hello and shake hands with the mother of the teacher with Javanese Kramai level. MI Al Islam Bonomerto used Indonesian and Javanese Krama level language in classroom learning for teachers and students communication.

The cultivation of Javanese-speaking culture of Krama in MI was expected to improve the learning process of students who not only knowledge- but also on the application of cultural values of education and religious, honest, tolerant, disciplined, hard work, creative, independent, democratic, know, the spirit of nationality, love the homeland, appreciate achievement, friendly/communicative, love peace, love to read, care environment, social care, and responsibility.

\section{Investment in MI Tegalwaton and MI Al Islam Bonomerto}

The results of Javanese 'Krama' language investigation in MI Tegalwaton and MI Al Islam Bonomerto could be seen from the teacher's evaluation of observation. This was evidenced by the already visible signs of student behavior consistently in each indicator in the madrasa was through learning activities in the classroom, madrasa and practice in everyday life.

Clarifying the results of the Javanese culture in MI Tegalwaton about the results obtained from the program is in the form of cargo-charge that becomes a focal point that can be applied and felt and practiced anywhere. While the result of cultural cultivation of Javanese Krama level in MI Al Islam Bonomerto obtained the values of manners and politeness.

Behavioristic theory states that the learning process is influenced 


\section{Mudarrisa: Jurnal Kajian Pendidikan Islam, Vol. 10, No. 2, 2018}

by the learning environment (Staddon, 2017). It is the process for analyzing inputs or stimuli in the form of speech and producing an output or response in the form of an understanding of the material of understanding. Language investment was a process of behavioral change as a result between stimulus and response (Richard, 2009: 300; Slavin, 2009: 143). This suggests that the role of the environment and madrasa greatly affect the child's language results. Florez (in Syafei \& Sekarini, 2016) said that speaking was an active process constructing meaning that involves producing and receiving and processing information.

The process of affective formation (attitude) was done in two ways, habituation and modeling. In the process of affective learning strategies using patterns habituation and modeling, the teacher should first explain to the students with an understanding of why it is done (Sanjaya, 2017:238-239). Investment conducted by teachers at MI Tegalwaton and MI Al Islam Bonomerto are as follows: First, teachers delivered the habituation patterns to students. Among them was the habit of speaking with Javanese Krama before the lesson begins. With that the students unconsciously memorized the Javanese vocabulary over and over every day. According to the author's observation, the process of habituation done by the teacher is good, but also need to give reinforcement so that students will try and eager to improve their positive attitude.

Second, teachers conducted attitude formation through modeling. The process of imitating was the process of imitating a child against another person against his or her idol or a respected person. The boy was 
given an understanding of why it was done. Master also gave good examples like the story of the example of the Prophet and the Apostle, Walisongo and the righteous. Teachers make planning strategy: a personal learning style or positive learning strategies; Active Strategy: an active approach to the learning task; Empathic strategy: a tolerant and outgoing approach to the target language and empathy with its speakers; Formal strategy: technical know-how about how to tackle a language; Experimental strategy: a methodical but flexible approach, developing the new language into an ordered system and constantly revising it; Semantic strategy: constant searching for meaning; Practice strategy: willingness to practice; Communication strategy: willingness to use the language in real communication; Monitoring strategy: self-monitoring and critical sensitivity to language use; Internalization strategy: developing a second language as a separate reference system and learning to think in it (Hong Shi, 2017: 24).

\section{Constraints in MI Tegalwaton and MI Al Islam Bonomerto}

Each implementation of learning both teachers and students has some obstacles that can during teaching and learning activities. MI Tegalwaton and MI Al Islam Bonomerto have several obstacles such as individual barriers for students, one of them because of limitations in the vocabulary of Javanese Krama. From these limitations then the students should be willing to ask friends or teachers in using appropriate vocabulary of Javanese Krama. Obstacles in understanding the vocabulary of Javanese 


\section{Mudarrisa: Jurnal Kajian Pendidikan Islam, Vol. 10, No. 2, 2018}

Krama experienced by students is as follows: (a) Still less appropriate in using vocabulary. (b) Difficulty memorizing vocabulary, for students who just learned Javanese manners experience difficulty pronunciation. (c) Students who are sometimes less interested in using Javanese Krama, so that makes students to be left behind.

Wahyuni and Syafei (2016) state that teachers have an important role to make students interested in learning Java Krama. In teaching Krama to young learner teachers need to provide help and guidance in comprehending Java Krama as a language by using the strategies which that can be used in changing and redefining their thought. In learning language the young learners are not the same as adults. Young learners need to pay attention to some element of Java languages such as pronunciation, spelling, structure, and vocabulary. To master Java language skills, the students must know the vocabularies of the language.

Another obstacle, teachers who teach at MI Tegalwaton and MI Al Islam Bonomerto are not graduates of Javanese native education. So it still requires more strategy to maximize the process of cultural cultivation of Javanese Krama. In addition to not the original graduates of Javanese language education, teachers have limitations in the monitoring of children outside the classroom. These limitations make the language mastery of children often change. Syafei and Sari (2013:128) suggest several factors influencing students understanding of Java Krama vocabulary such as the lack of students' knowledge, the low quality of students' assignments, inappropriate technique and approaches of 


\section{Mudarrisa: Jurnal Kajian Pendidikan Islam, Vol. 10, No. 2, 2018}

teaching used by the teacher.

\section{CONCLUSION}

Based on cultural investment of Javanese 'Krama' language in MI Tegalwaton Subdistrict of Tengaran and MI Al Islam Bonomerto Subdistrict Suruh Regency Semarang Year 2018 and study of library which have presented in this paper, the writer conclude that cultivation of Javanese 'Krama' language centered on learners and given freedom to active opinion and allow time for direct practice. The cultivation of Javanese-speaking culture of Krama uses individual principles and is closer to the students to be well communicated. The method used by teachers is the method of practice.

The process of cultural investment of Javanese 'Krama' language at MI Tegalwaton begins with 4S (Smiling, Greetings, Accosting, and Mannering) the morning of the students with the father's mother teacher and continued to pray before studying. In habituation in the classroom teachers also apply the use of Javanese Krama when the child. Meanwhile, in MI Al Islam Bonomerto, the cultivation of Javanese culture of Krama was implemented during learning inside the classroom. The result of cultural investment of Javanese 'Krama' language in MI Tegalwaton and MI Al Islam Bonomerto was behavior of learners who began to be consistent when in the madrasa is through learning activities in the classroom and practice in everyday life. 


\section{REFERENCES}

Anas, Z. (2011). Pendekatan Brain Based Learning dalam Penanaman Nilai Budaya Melalui Pendidikan Formal. Jurnal Komunitas, Volume 3, 150-158.

Budiman, A. (2017). Behaviorism in Foreign Language Teaching Methodology. English Franca, 1(02), 101-114.

Chaer, A. (2009). Psikolinguistik Kajian Teoritik. Jakarta: Rineka Cipta.

Cresswel. (2007). Quantitative Inquiry $\mathcal{E}$ research design: Choosing among five approaches. California: Sage Publication Inc.

Djiwandono, P. I. (2014). Pengembangan Pembelajaran Sastra Lokal untuk Membangun Karakter Positif Anak Sekolah Dasar. In Proceeding of Seminar NAsional Paramasastra (1-16). Surabaya: Universitas Negeri Surabaya.

Ghazali, S. (2000). Pemerolehan dan Pengajaran Bahasa Kedua. Jakarta: Dikti Depdiknas.

Hong Shi. (2017). Learning Strategies and Classification in Education. Institute for Learning Styles Journal, Volume 1, 24.

Ksuchak, E. P. (2009). Educational Psychology Windows on Classrooms. New Jersey: Merrill Prentice Hall.

Ni Wayan Sartini. (2009). Menggali Nilai Kearifan Lokal Budaya Jawa Lewat Ungkapan (Bebasan, Saloka dan Peribahasa). Jurnal Ilmiah Bahasa dan Sastra, V, 28-29.

Owens, R. (2012). Language Development an Introduction. New York: Macmillan Publising Company.

Poedjosoedarmo, S. (2017). Language Propriety in Javanese. Journal of Language and Literature, 17(1), 1-9.

Rachim, R. L., \& Anshori, H. F. (2007). Nilai budaya Jawa dan perilaku nakal remaja Jawa. Indigenous: Jurnal Ilmiah Psikologi, 9(1), 30-43.

Richard, J. (2009). Methods in Language Teaching. Cambridge: Cambridge University Press.

Sanjaya, Wina \& Andi Budimanjaya (2017). Paradigma Baru Mengajar, Jakarta: Kencana. 
Sedyawati, E. (2003). Warisan budaya takbenda: masalahnya kini di Indonesia.

Pusat Penelitian Kemasyarakatan dan Budaya, Lembaga Penelitian, Universitas Indonesia.

Slavin. (2009). Belajar dan Pembelajaran. Jakarta: Pranada Media Group.

Suri, Mutya. And Isyam, Amri (2013) Teaching Vocabulary to Elementary

School Students Through Colouring Pictures Activity. Journal of English Language Teaching, Vol. 1 No. 2, Maret 2013, Serie F

Suwardi, Anitah, W. S., Akhyar, M. \& Asrowi. (2017). Gender Bias in Islamic Textbooks for Muslim Children in Indonesia. Attarbiyah: Journal of Islamic Culture and Education. 2 (2). $214-235$.

Staddon, J. (2017). Theoretical Behaviorism. In In Behavior and Philosophy (pp. 217-241).

Utari, N. R. D. (2012). Kemampuan Berbahasa Jawa pada Siswa Sekolah Dasar di SDN Tandes Kidul I/110 Surabaya. Skriptorium, 1(3), $83-85$.

Wahyuni, Desri and Syafei, AFR (2016) The Use of Action Bingo Game In Teaching Vocabulary to Elementary School Students. JELT Vol 5 No 1 Serie C September 2016

Wedhawati. (2006). Tata Bahasa Jawa Mutakhir. Yogyakarta: Kanisius. 